Syntax Literate: Jurnal Ilmiah Indonesia p-ISSN: 2541-0849

e-ISSN: 2548-1398

Vol. 6, Spesial Issue No. 1, November 2021

\title{
EFEKTIFITAS TEKNIK REBOZO DALAM LAMA PERSALINAN KALA I FASE AKTIF PADA IBU BERSALIN PRIMIGRAVIDA DI WILAYAH KABUPATEN TAPANULI UTARA BULAN JANUARI S/D OKTOBER 2020
}

\author{
Ganda Agustina Hartati Simbolon, Urhuhe Dena Siburian \\ Politeknik Kesehatan Kemenkes RI Medan, Indonesia \\ Email: agustinahartati81@gmail.com, denasiburian2019@gmail.com
}

\begin{abstract}
Abstrak
Nyeri saat persalinan merupakan kondisi fisiologis yang secara umum dialami oleh hampir semua ibu bersalin, apabila nyeri persalinan tidak diatasi akan menyebabkan terjadinya partus lama. Teknik rebozo adalah cara nonfarmakologi untuk membantu mengelola rasa sakit selama persalinan. Rebozo adalah kain panjang yg biasa dipakai wanita meksiko untuk berkegiatan sehari-hari (memanggul, menggendong bayi, selimut dll). melilitkan rebozo ke sekeliling panggul dan bokong ibu hamil lalu menggoyangkannya selama kala I berlangsung. Ayunan dari rebozo dianggap mampu membuat sang ibu rileks serta membantu memposisikan bayi ke jalan lahir sehingga dapat mempercepat proses persalinan. Jenis penelitian ini adalah penelitian comparative dengan desain eksperimen semu. Tujuan Penelitian ini adalah untuk mengetahui efektifitas Teknik Rebozo dalam ama persalinan Kala I fase aktif pada ibu primigravida yang berjumlah 14 orang untuk kelompok intervensi dan 14 orang kelompok kontrol. Penelitian dilakukan pada 6 Puskesmas di wilayah Kabupaten Tapanuli Utara dengan teknik pengambilan sampel consecutive sampling dan memenuhi kriteria inklusi. Hasil penelitian diperoleh seluruh responden dalam usia reproduksi $(20-35$ tahun $)$ umumnya pendidikan SMA, Jenis pekerjaan umumnya PNS 57,4\% dan Petani $(71,4 \%)$, semua persalinan didampingi oleh suami. Hasil uji menggunakan uji independent $t$ test nilai $\alpha=0,00(<0,05)$, nilai mean rank kelompok intervensi $(7,43)>$ kelompok kontrol $(4 ., 00)$ yang menunjukkan ada perbedaan rata-rata lama persalinan kala I fase aktif sehingga teknik rebozo sangat efektif untuk mempercepat lama persalinan kala I fase aktif. Teknik rebozo sangat efektif untuk mengurangi nyeri persalinan dan mempercepat proses persalinan. Bidan diharapkan dapat menerapkan Teknik Rebozo menjadi salah salah bentuk asuhan persalinan kala I untuk mempercepat persalinan.
\end{abstract}

Kata Kunci: rebozo; lama persalinan
Abstract
Pain during labor is a physiological condition that is generally experienced by almost all maternity mothers, if labor pain is not overcome it will cause prolonged labor. The rebozo technique is a non-pharmacological way to help manage pain during labour. Rebozo is a long cloth commonly used by Mexican women for daily 
Efektifitas Teknik Rebozo dalam Lama Persalinan Kala I Fase Aktif pada Ibu Bersalin Primigravida di Wilayah Kabupaten Tapanuli Utara Bulan Januari s/d Oktober 2020

activities (carrying, carrying babies, blankets, etc.). wrapping the rebozo around the pelvis and buttocks of pregnant women and then rocking it during the first stage. The swing of the rebozo is considered to be able to relax the mother and help position the baby into the birth canal so that it can speed up the delivery process. This type of research is a comparative study with a quasi-experimental design. The purpose of this study was to determine the effectiveness of the Rebozo technique in the active phase of the first stage of labor in primigravida mothers, which consisted of 14 people for the intervention group and 14 people for the control group. The study was conducted at 6 Puskesmas in North Tapanuli Regency with consecutive sampling technique and met the inclusion criteria. The results obtained that all respondents in reproductive age (20-35 years) generally had high school education, the type of work was generally civil servants $57.4 \%$ and farmers $(71.4 \%)$, all deliveries were accompanied by their husbands. The results of the test using the independent t test, the value of $=0.00(<0.05)$, the mean rank of the intervention group $(7.43)>$ the control group (4.00) which shows there is a difference in the average length of the first stage of labor active phase so that the rebozo technique is very effective in accelerating the length of the first stage of labor in the active phase. The rebozo technique is very effective in reducing labor pain and speeding up the labor process. Midwives are expected to be able to apply the Rebozo Technique as a form of first stage delivery care to speed up delivery.

Keywords: rebozo; labor time

Received: 2021-10-20; Accepted: 2021-11-05; Published: 2021-11-20

\section{Pendahuluan}

Kesehatan merupakan hak asasi manusia dan menjadi salah satu unsur kesejahteraan sesuai dengan cita-cita bangsa Indonesia yang tercantum dalam Pancasila dan Undang-Undang Dasar Republik Indonesia Tahun 1945 yang harus diwujudkan. Kesehatan merupakan kebutuhan bagi semua manusia yang menjadi indikator kualitas hidup. Indonesia merupakan Negara berkembang yang masih memerlukan upaya peningkatan kualitas hidup masyarakatnya secara komprehensif, adil dan merata. Perhatian Negara diharapkan menyelenggarakan upaya kesehatan yang berhasil guna dan berdaya guna (Notoatmodjo, 2012).

Hasil Riset Kesehatan Dasar (RISKESDAS) tahun 2010 menunjukkan angka kejadian Sektio caesarea (SC) di Indonesia sebesar 15,3\% dari sampel 20.591 ibu yang melahirkan. World Health Organization (WHO) menetapkan batasan maksimum proporsi persalinan secara SC sebesar $10 \%$. Kecenderungan meningkatnya proporsi persalinan seksio sesarea perlu mendapatkan perhatian karena tidak adanya bukti kemanfaatan dalam menurunkan angka kematian ibu dan bayi (Riskesdas, 2013).

Persalinan dengan SC memang akan membuat ibu hamil terbebas dari rasa nyeri yang dialami selama bersalin. Ada beberapa risiko atau komplikasi dari melahirkan secara SC diantaranya adalah Infeksi, Perdarahan, terjadinya bekuan darah, reaksi anestesi, cedera saat pembedahan. Selain pada inbu, bisa juga menimbulkan risiko pada bayi, seperti : gangguan pernafasan, kulit tergores, dan rendahnya ikatan kasih sayang 
(bonding atacment ) serta inisiasi menyusui dini yang diperoleh bayi baru lahir (Pane MDC, 2019).

Fenomena tingginya angka SC juga terjadi di RSUD Tarutung. Hasil survey awal diperoleh jumlah persalinan mulai Januari s/d September 2019 sebanyak 1.107 persalinan, rata-rata perbulan 21 persalinan. Dari jumlah tersebut diperoleh informasi persalinan SC sebanyak 917 (82\%). Ini berarti kasus persalinan dengan SC lebih banyak dibanding normal (18\%). Berdasarkan wawancara yang dilakukan di Ruang Kebidanan, tingginya angka SC tidak hanya disebabkan oleh indikasi medis tapi juga indikasi non medis seperti permintaan sendiri dikarenakan takut akan nyeri yang tidak tertahankan sewaktu persalinan.

Persalinan merupakan suatu peristiwa yang sangat penting dalam kehidupan dan memiliki arti yang berbeda pada setiap wanita. Bagi wanita yang pertama kali melahirkan, proses persalinan mungkin dirasa menakutkan, dan dengan belum adanya pengalaman akan memunculkan kecemasan dan ketakutan yang berlebih (Rukiah, 2009). Rasa nyeri adalah hal normal sebagai akibat dari kontraksi rahim juga tekanan/dorongan kepala bayi pada jalan rahim, namun rasa nyeri bisa bertambah dan menjadi tidak nyaman jika ditambah dengan rasa takut, khawatir atau kelelahan. Hal ini bisa mempengaruhi ibu bersalin sehingga berpotensi merubah rasa sakit menjadi "penderitaan" (Simbolon, Siburian, \& SKM, 2021). Salah satu cara mengurangi rasa sakit dari persalinan adalah dengan menggunakan teknik Rebozo.

Teknik rebozo adalah cara nonfarmakologi atau tanpa menggunakan obat (tradisional) untuk membantu mengelola rasa sakit selama persalinan. Teknik ini berasal dari Meksiko dimana wanita disana mempunyai tradisi menggunakan rebozo sebelum, selama dan setelah kelahiran. Rebozo adalah kain panjang yg biasa dipakai wanita meksiko untuk berkegiatan sehari - hari (memanggul, menggendong bayi, selimut dll). melilitkan rebozo ke sekeliling panggul dan bokong ibu hamil, lalu menggoyangkannya selama proses persalinan berlangsung. Ayunan dari rebozo dianggap mampu membuat sang ibu rileks serta membantu memosisikan bayi ke jalur lahir (Rebozo, 2016).

Teknik Rebozo biasanya dilakukan pada ibu hamil setelah usia kehamilan 28 minggu, dapat juga dilaksanakan selama persalinan. Pada fase awal persalinan, dan setelah memasuki fase aktif, dilakukan dengan Teknik Shake The Apple Tree, merupakan salah satu yang paling umum dilakukan pada pinggul wanita yang akan melahirkan, dengan gerakan yang terkontrol untuk membantu mengayunkannya dari sisi ke sisi lain sedikit demi sedikit. Menurut Elloianza dalam (Simbolon et al., 2021) biasanya untuk praktisi yang membantu ibu dalam melakukan teknik rebozo menggunakan posisi jongkok atau berdiri dengan sedikit menunduk.

Awal mulai persalinan, penolong persalinan maupun pendampingnya mulai menarik kain dan menggoyang-goyangkan bagian perut ibu secara lembut. Gerakan ini membantu ibu merasa lebih nyaman. Lilitan yang tepat akan membuat ibu merasa seperti dipeluk dan memicu keluarnya hormone oksitosin yang bisa membantu proses persalinan lebih lancar. Tidak hanya sebatas kenyamanan saat persalinan, Rebozo juga 
membantu memberikan ruang pelvic yang lebih luas untuk ibu sehingga bayi lebih mudah menuruni panggul dan proses persalinan lebih cepat (Simbolon et al., 2021).

WHO telah menyatakan bahwa kurangnya studi tentang praktik tradisional seharusnya tidak menjadi hambatan dalam penerapan atau pengembangannya. Ada dua makalah yang diterbitkan dalam jurnal peer-review tentang penggunaan rebozo selama persalinan. Yang pertama adalah Studi kualitatif yang dilakukan Iversen dkk tahun 2017 di Denmark. Respondennya adalah 17 ibu postpartum yang pernah menggunakan rebozo selama persalinan. Sebagian besar responden mengatakan bahwa mereka menggunakan rebozo untuk malposisi janin karena bayi mereka tidak dalam posisi optimal. Hanya satu dari 17 yang menggunakan rebozo untuk menghilangkan rasa sakit. Rebozo dilakukan dengan posisi berdiri, tangan dan lutut dan berbaring. Secara keseluruhan, reponden memiliki pengalaman positif saat menggunakan rebozo, menciptakan sensasi yang mengurangi rasa sakit sehingga persalinan menjadi lebih santai, pasangan dan bidan juga lebih aktif terlibat dalam proses persalinannya. Hasil lainnya adalah sebelum tahun 2014, teknik Rebozo hanya digunakan pada sekitar 2\% dari persalinan normal yang direncanakan. Namun, setelah tahun 2016, teknik rebozo digunakan dengan sekitar 9\% wanita Denmark (Iversen et al., 2017)

Di Indonesia, teknik Rebozo ini sudah mulai diperkenalkan oleh tim pengembang Hipnobirthing dan Prenatal gentle birth. Lanny Kuswandy dan Yessie Aprilia dalam blog nya menyebutkan bahwa teknik ini memberi manfaat dalam menambah kenyamanan ibu dan mempercepat proses persalinan. Meskipun penelitian tentang Rebozo di Indonesia masih minim, namun telah banyak bidan menerapkan teknik ini pada klien mereka.

Kabupaten Tapanuli Utara terdiri dari 15 Kecamatan dengan 17 Puskesmas dan 1 Rumah Sakit sebagai pusat rujukan untuk tingkat daerah. Sesuai dengan Permenkes No. 97 Tahun 2014 pasal 14 ayat 1 yang berbunyi bahwa persalinan harus dilakukan di fasilitas pelayanan kesehatan, Pemerintah Kabupaten Tapanuli Utara juga menerapkan peraturan tersebut. Hasil studi pendahuluan yang dilakukan oleh peneliti, ada 4 Puskesmas yang memiliki karakteristik yang hampir sama (distribusi penduduk yang heterogen,dan jarak tempuh ke pusat kota), sehingga peneliti menetapkan Puskesmas ini menjadi lokasi penelitian, yaitu Puskesmas Hutabaginda, Puskesmas Siatas Barita, Puskesmas Sipoholon dan Puskesmas Sitada-Tada. Masing-masing Puskesmas dilaporkan jumlah persalinan rata-rata 15 persalinan setiap bulannya, secara umum ibu primigravida merasa cemas, takut akan nyeri dan lamanya proses persalinan, sehingga ada yang memilih persalinan dengan tindakan SC di Rumah Sakit.

Melihat budaya masyarakat yang terbiasa ke tukang pijat termasuk ibu hamil untuk mengatasi nyeri pinggang diakhir kehamilan, peneliti berasumsi teknik Rebozo ini akan mudah diterima oleh masyarakat, hal inilah yang menarik minat peneliti untuk melakukan penelitian tentang efektifitas teknik Rebozo dalam intensitas nyeri dan lama persalinan Kala I di wilayah Kabupaten Tapanuli Utara pada bulan Januari hingga Oktober 2020. 


\section{Metode Penelitian}

\section{Metode pengumpulan data}

1) Menjelang akhir kehamilan, peneliti mendatangi ibu hamil primigravida untuk meminta kesediaan ibu menjadi responden penelitian saat persalinannya sekaligus memperkenalkan teknik rebozo pada ibu dan keluarga (suami) berupa penjelasan tentang teknik Rebozo dan mengajarkan tentang teknik Rebozo sehingga pendamping dapat mempraktekkan langsung pada ibu saat persalinannya nanti. Bila ibu dan keluarga menyetujui perlakuan teknik rebozo maka ibu ditetapkan sebagai kelompok ekperimen dan meminta nomor kontak ibu dan bila sewaktu-waktu tanda2 persalinan telah ada maka ibu hamil primigravida segera menghubungi peneliti agar peneliti dapat mengetahui lama persalinan.

2) Ibu hamil primigravida yang tidak bersedia dilakukan teknik rebozo saat perealinannya nanti, namun bersedia dilakukan pengukuran lama dijadikan sebagai kelompok kontrol,

3) Pengumpulan data dimulai pada saat ibu mulai merasakan adanya tanda-tanda persalinan (mules yang semakin sering, keluar lendir bercampur darah atau keluar air-air dari jalan lahir), kelompok ekperimen dan kelompok kontrol mulai mengisi informed consent penelitian dan mendapat penjelesan kembali mengenai prosedur teknik rebozo.

4) Bila ibu sudah memasuki fase aktif (pembukaan sudah $4 \mathrm{~cm}$ ), dilakukan pengukuran untuk mengetahui lama persalinannnya, peneliti melakukan pengukuran kontraksi uterus dengan menggunakan stopwatch dan mengisinya dalam lembar partograph, untuk mengetahui pembukaan serviks dilakukan dengan pemeriksaan dalam pada pasien lelu mengisinya dalam lembar partograph

5) Selanjutnya setelah pembukaan serviks sudah diatas $6 \mathrm{~cm}$, teknik rebozo mulai dilakukan selama 2-5 menit yang awalnya dilaksanakan oleh peneliti, selanjutnya dilakukan oleh suami saat terjadi kontraksi atau sesuai dengan keinginan ibu yang membuat ibu merasa lebih nyaman hingga pembukaan 10 cm (lengkap).

6) Diluar kontraksi, ibu diminta untuk memberi tanda yang terdapat pada alat ukur VAS sesuai dengan petunjuk yang telah disampaikan sebelumnya.

\section{Pengolahan Data}

Pengolahan data dilakukan dengan tahapan sebagai berikut (Notoatmodjo, 2012):

1) Pemeriksaan data (editing)

Kegiatan ini dilakukan untuk memeriksa ulang kelengkapan kuesioner/data yang masuk. Editing meliputi kegiatan memastikan bahwa setiap pernyataan dalam kuesioner terisi semua, jelas atau terbaca, konsistensi 
jawaban, relevansi jawaban dengan pernyataannya yang secara keseluruhan berkaitan dengan kemungkinan kesalahan.

2) Pengkodean data (coding)

Pengkodean data merupakan proses penyusunan secara sistematis data mentah (data dalam kuesioner) kedalam bentuk yang mudah dibaca oleh komputer. Data yang berbentuk huruf kemudian diubah menjadi data yang berbentuk angka atau bilangan. Tujuan pemberian kode adalah untuk memudahkan pada saat melakukan analisis data sehingga dapat mempercepat pada saat entry data.

Pada penelitian ini, ada varibael yang memerlukan coding dengan memberi kode pada setiap butir kuesioner dan variabel penelitian. Tujuan dilakukan pemberian kode agar memberikan kemudahan dalam pengolahan data. Selain itu dilakukan system skoring untuk memudahkan peneliti menentukan lama dan kemajuan persalinan, yaitu :

a. Kontraksi Uterus :

a) Skor 3, bila kontraksi uterus $>3 \times 10$ menit dengan durasi $>40$ detik

b) Skor 2, Bila kontraksi uterus 3 x/10 menit dengan durasi 20 - 40 detik

c) Skor 1 bila kontraksi $<3$ x/10 menit dengan durasi $<20$ detik

b. Pembukaan serviks

a) Skor 3 , bila pembukaan serviks $>1 \mathrm{~cm} / \mathrm{jam}$

b) Skor 2 , bila pembukaan serviks $1 \mathrm{~cm} / \mathrm{jam}$

c) Skor 1 , bila pembukaan serviks $<1 \mathrm{~cm} / \mathrm{jam}$

c. Lama Persalinan pre test

a) Skor 3 , bila lama persalinan pre test $<2$ jam

b) Skor 2 , bila lama persalinan pre test 2 jam

c) Skor 1 , bila lama persalinan pre test $>2$ jam

d. Lama Persalinan post test

a) Skor 3 , bila lama persalinan post test $<4$ jam

b) Skor 2 , bila lama persalinan post test 4 jam

c) Skor 1 , bila lama persalinan post test $>4$ jam

3) Memasukkan data (data entry/processing)

Memproses data untuk dianalisis, pemrosesan data dilakukan dengan cara memasukkan data dari masing-masing responden kedalam program atau software di komputer.

4) Pembersihan data (cleaning)

Pembersihan data dilakukan untuk memastikan bahwa seluruh data yang sudah dimasukkan telah sesuai dengan yang sebenarnya. Kegiatan pengecekan kembali data yang sudah dimasukkan dilakukan untuk mengetahui kemungkinan kesalahan-kesalahan kode maupun ketidaklengkapan data.

\section{Teknik analisis data}

1) Analisa Univariat 
Untuk melihat distribusi frekuensi dari masing-masing variable dengan menggunakan tabel distribusi frekuensi.

2) Analisa Bivariat

Analisis bivariat yang digunakan untuk membuktikan perbedaan intensitas nyeri dan lama persalinan pada kelompok intervensi sebelum dan setelah dilakukan penelitian/ perlakuan serta perbedaan intensitas nyeri dan lama persalinan pada kelompok kontrol sebelum dan setelah dilakukan penelitian/ perlakuan. Sebelum dilakukan analisa bivariat maka dilakukan uji homogenitas. Uji homogentas ini bertujuan untuk mengetahui apakah data dalam variabel $\mathrm{x}$ dan $\mathrm{y}$ bersifat homogen atau tidak. Selain itu juga dilakukan uji normalitas data. Jika data hasil penelitian berdistribusi normal maka analisa bivariat akan dilakukan dengan Paired t Test. Namun, jika data tidak berdistribusi normal maka analisa bivariat dilakukan menggunakan uji alternatif yaitu uji wilcoxon dan Mann Whitney dengan taraf kepercayaaan $95 \%$. Sedangkan untuk membuktikan efektifitas teknik Rebozo terhadap lama persalinan pada kelompok intervensi dan kontrol setelah diberikan intervensi, penelitian ini menggunakan uji Independent sample T-test. \% (Arikunto, 2010) dan (Hidayat, 2007).

\section{Hasil dan Pembahasan}

\section{Hasil Penelitian}

Telah dilakukan penelitian tentang efektifitas teknik Rebozo dalam intensitas nyeri dan lama persalinan kala I fase aktif pada ibu bersalin primigravida di wilayah kabupaten Tapanuli Utara tahun 2020 terhitung mulai bulan Februari dengan pengambilan data terakhir tanggal 29 Oktober 2020. Responden penelitian terdidir dari kelompok intervensi yang diberi perlakuan teknik rebozo dan kelompok kontrol berupa dukungan suami dan keluarga yang mana setiap kelompok masing-masing berjumlah 14 orang, dengan sebaran sebagai berikut sebagai berikut :

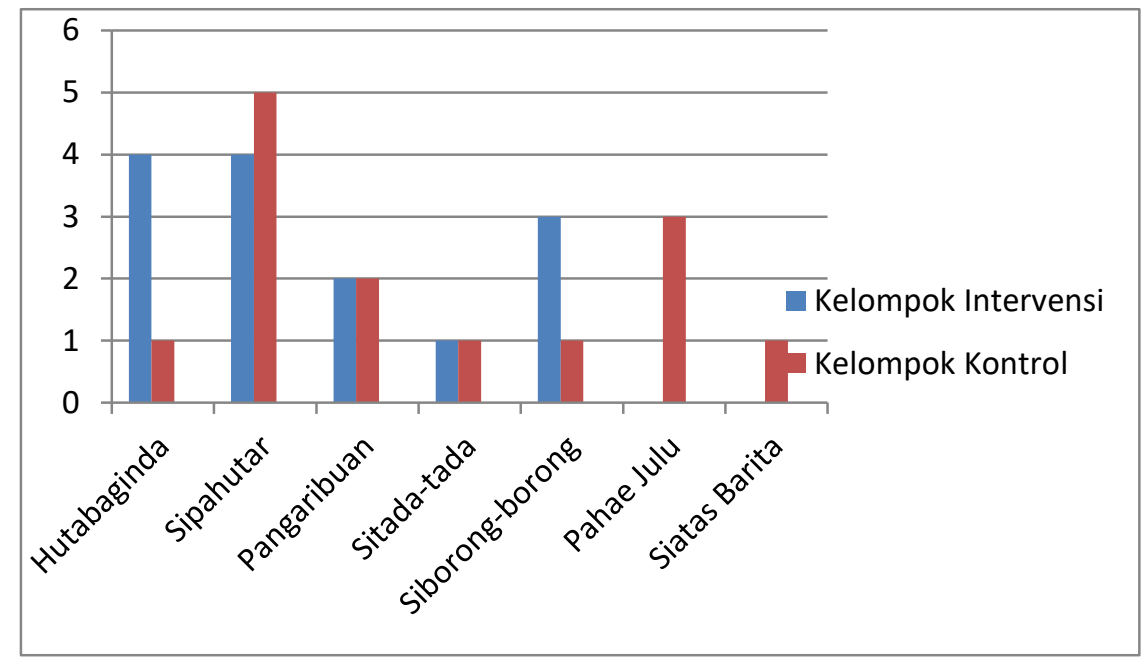

Grafik 1 
Efektifitas Teknik Rebozo dalam Lama Persalinan Kala I Fase Aktif pada Ibu Bersalin Primigravida di Wilayah Kabupaten Tapanuli Utara Bulan Januari s/d Oktober 2020

\section{Sebaran Tempat Persalinan responden Penelitian Pada Kelompok Intervensi dan Kelompok Kontrol}

Grafik diatas menunjukkan sebaran tempat persalinan pada kelompok intervensi yang berwarna biru, sedangkan kelompok kontrol berwarna hijau. Kelompok intervensi lebih banyak diperoleh dari Puskemas Hutabaginda dan Puskesmas Sipahutar masing-masing 4 orang, sedangkan kelompok kontrol lebih banyak dari Puskesmas Sipahutar yaitu 5 orang.

\section{Analisis Univariat}

Analisis univariat dilakukan untuk mengetahui distribusi frekuensi dari setiap variabel pada kelompok intervendi dan kelompok kontrol. Variabel tersebut diantaranya karakteristik responden (usia, tingkat Pendidikan, jenis pekerjaan, dan bentuk dukungan suami), intensitas nyeri dan lama persaliann kala I fase aktif pada ibu bersalin primigravida. Sebaran data dapat dilihat pada tabel dibawah ini:

1) Karakteristik Responden Penelitian

Karakteristik responden kelompok intervensi dan kelompok kontrol berdasarkan umur, tingkat pendidikan, jenis pekerjaan dan bentuk dukungan suami

\section{Tabel 1}

\section{Distribusi Karakteristik Responden}

\begin{tabular}{|c|c|c|c|c|c|}
\hline \multirow{3}{*}{ No. } & \multirow{3}{*}{$\begin{array}{c}\text { Karakteristik } \\
\text { Responden }\end{array}$} & \multicolumn{4}{|c|}{ Jumlah } \\
\hline & & \multicolumn{2}{|c|}{ Kelompok Intervensi } & \multicolumn{2}{|c|}{ Kelompok Kontrol } \\
\hline & & $\mathrm{n}$ & $\%$ & $\mathrm{~N}$ & $\%$ \\
\hline A & \multicolumn{5}{|c|}{ Kelompok Umur (Tahun) } \\
\hline 1. & $<20$ & 0 & 0 & 0 & 0 \\
\hline 2. & $20-35$ & 14 & 100 & 14 & 100 \\
\hline 3. & $>35$ & 0 & 0 & 0 & 0 \\
\hline $\mathrm{B}$ & \multicolumn{5}{|l|}{ Tingkat Pendidikan } \\
\hline 1. & SD & 1 & 7,1 & 0 & 0 \\
\hline 2. & SMP & 1 & 7,1 & 1 & 7,1 \\
\hline 3. & SMA & 8 & 57,4 & 12 & 85,8 \\
\hline 4. & PT & 4 & 28,4 & 1 & 7,1 \\
\hline $\mathrm{C}$ & \multicolumn{5}{|l|}{ Jenis Pekerjaan } \\
\hline 1. & PNS & 8 & 57,4 & 0 & 0 \\
\hline 2. & Honorer & 2 & 14,2 & 0 & 0 \\
\hline 3. & Swasta & 1 & 7,1 & 4 & 28,6 \\
\hline 4. & Petani & 1 & 7,1 & 10 & 71,4 \\
\hline 5. & Ibu Rumah Tangga & 2 & 14,2 & 0 & 0 \\
\hline $\mathrm{D}$ & \multicolumn{5}{|c|}{ Dukungan Suami } \\
\hline 1. & Rebozo & 8 & 57,4 & 0 & 0 \\
\hline 2. & Elus punggung & 1 & 7,1 & 2 & 14,3 \\
\hline 3. & Pijat kaki & 1 & 7,1 & & \\
\hline 4. & Beri semangat & 3 & 21,3 & 9 & 64,3 \\
\hline 5. & Beri makan dan minum & 1 & 7,1 & 1 & 7,1 \\
\hline
\end{tabular}




\begin{tabular}{llllll}
\hline 6. & Pijat punggung & 0 & 0 & 2 & 14,3 \\
\hline
\end{tabular}

Dari hasil penelitian diketahui bahwa semua responden (100\%) eksperimen maupun kelompok kontrol berada pada usia reproduksi sehat yaitu 20 - 35 tahun dan mayoritas tingkat pendidikan SMA pada kelompok intervensi 8 orang $(57,4 \%)$ dan pada kelompok kontrol 12 orang $(85,8 \%)$. Dari jenis pekerjaan kelompok intervensi mayoritas PNS yaitu 8 orang $(57,4 \%)$ dan pada kelompok kontrol mayoritas pekerjaan sebagai petani 10 orang $(71,4 \%)$ dan mayoritas responden bekerja sebagai petani yaitu 8 orang $(57,2 \%)$.

Kelompok intervensi datang ke Puskesmas untuk bersalin dengan didampingi oleh suami dan beberapa orang ikut juga mertua dan keluarga lain. Suami responden memberi dukungan dengan bersedia melakukan teknik Rebozo pada ibu ada 8 orang $(57,4 \%)$. Pada kelompok kontrol tidak dilakukan teknik Rebozo, suami responden memberi dukungan kepada istri dengan memberi semangat sebanyak 9 orang $(64,3 \%)$.

Kelompok intervensi yang berjumlah 14 orang datang ke Puskesmas untuk bersalin dengan didampingi oleh suami dan beberapa orang ikut juga mertua dan keluarga lain. Suami responden 57,4 \% memberi dukungan dengan bersedia melakukan teknik Rebozo pada ibu. Ibu bersalin mayoritas dari Puskesmas Hutabaginda dan Sipahutar. Masing-masing berjumlah 4 orang $(28,6 \%)$.

2) Lama dan Kemajuan Kala I Fase Aktif Pada Responden

Tabel 2

Lama dan Kemajuan Kala I Fase Aktif Ibu Bersalin Primigravida Pada kelompok Intervensi dan Kelompok Kontrol

\begin{tabular}{|c|c|c|c|c|c|c|c|c|c|}
\hline \multirow[t]{4}{*}{ No } & \multirow[t]{4}{*}{ Kriteria } & \multicolumn{8}{|c|}{ Responden } \\
\hline & & \multicolumn{4}{|c|}{ Kelompok Intervensi } & \multicolumn{4}{|c|}{ Kelompok Kontrol } \\
\hline & & \multicolumn{2}{|c|}{ Sebelum } & \multicolumn{2}{|c|}{ Sesudah } & \multicolumn{2}{|c|}{ Sebelum } & \multicolumn{2}{|c|}{ Sesudah } \\
\hline & & $\mathrm{F}$ & $\%$ & $\mathrm{f}$ & $\%$ & $\mathrm{~F}$ & $\%$ & $\mathrm{f}$ & $\%$ \\
\hline 1 & Cepat & 4 & 28,6 & 10 & 71,4 & 0 & 0 & 0 & 0 \\
\hline 2 & Normal & 4 & 28,6 & 4 & 28,6 & 10 & 71,4 & 9 & 64,3 \\
\hline 3 & Lambat & 6 & 42,8 & 0 & 0 & 4 & 28,6 & 5 & 35,7 \\
\hline & Jumlah & 14 & 100 & 14 & 100 & 14 & 100 & 14 & 100 \\
\hline
\end{tabular}

Tabel 5.3. menunjukkan lama kala I pada kelompok intervensi sebelum perlakuan rebozo pada umumnya lambat yaitu 42,9\%, sesudah intervensi umumnya menjadi cepat $(71,4,1 \%)$. Sedangkan pada kelompok kontrol lama kala I umumnya normal baik pada pretest $(71,4 \%)$ dan post test $(64,3 \%)$.

\section{Analisis Bivariat}

Analisis bivariat digunakan untuk mengetahui perbedaan intensitas nyeri dan lama persalinan pada kelompok intervensi sebelum dan setelah dilakukan 
penelitian/ perlakuan serta perbedaan intensitas nyeri dan lama persalinan pada kelompok kontrol sebelum dan setelah dilakukan penelitian/ perlakuan.

1) Perlakuan Rebozo Terhadap Lama Persalinan Kala I Fase Aktif

Sebelum dilakukan analisa bivariat maka dilakukan uji homogenitas. Uji homogentas ini bertujuan untuk mengetahui apakah data dalam variabel $\mathrm{x}$ dan $\mathrm{y}$ bersifat homogen atau tidak. Selain itu juga dilakukan uji normalitas data.

Menurut (Cahyati, Nurachmah, \& Hastono, 2013) untuk mengetahui suatu data berdistribusi normal ada 3 cara untuk mengetahuinya yaitu: (1) dilihat dari grafik histogram, bila bentuknya menyerupai lonceng (bel shape), berarti berdistribusi normal, (2) menggunakan nilai skewness dan standar errornya, bila nilai skewness dibagi standar errornya menghasilkan angka $\leq 2$, maka distribusinya normal, (3) uji Shapiro-wilk karena metode ini efektif dan valid digunakan untuk sampel berjumlah kecil.

2) Perbedaan lama persalinan Kala I fase aktif pada ibu primigravida sebelum dan sesudah perlakuan teknik rebozo

Perbedaan lama persalinan kala I fase aktif pada ibu primigravida sebelum dan sesudah perlakuan teknik rebozo dengan menggunakan Paired t test yang sebelumnya telah dilakukan uji normalitas data, terdapat pada tabel dibawah ini:

Tabel 3

Perbedaan lama persalinan kala I fase aktif pada ibu primigravida sebelum dan sesudah perlakuan teknik rebozo $(n=14)$

\begin{tabular}{|c|c|c|c|c|c|c|c|}
\hline \multirow{2}{*}{$\begin{array}{l}\text { Kelompok } \\
\text { Intervensi }\end{array}$} & \multicolumn{4}{|c|}{ Lama Kala I Fase Aktif } & \multirow[t]{2}{*}{ Korelasi } & \multirow[t]{2}{*}{ Sig } & \multirow[t]{2}{*}{ Sig.(2-tailed) } \\
\hline & Mean & $\mathbf{N}$ & $\begin{array}{l}\text { Std } \\
\text { Dev }\end{array}$ & $\begin{array}{c}\text { SE } \\
\text { Mean }\end{array}$ & & & \\
\hline Pre Test & 5,00 & 14 & 2,112 & 0,565 & 0,244 & 0,400 & 0,001 \\
\hline Post Test & 7,43 & 14 & 1,342 & 0,359 & & & \\
\hline
\end{tabular}

Tabel 3 dapat di ketahui bahwa rata rata lama kala I fase aktif pada pre test diperoleh 5, sedangkan pada post test diperoleh 7,43. Nilai standar deviasi pre test 2,112 dan post test 1,342. Standar error mean untuk pre test 0,565 dan post test 0,359 . Karena rata - rata lama persalinan post test $7,43>$ pre test 5 , maka secara deskriftif ada perbedaan lama persalinan kala I antara pre test dan post test, yang artinya persalinan kala 1 fase aktif lebih cepat pada kelompok post test.

\section{Uji hipotesis 1}

Ho: Tidak Ada perbedaan lama persalinan kala I fase aktif pada ibu primigravida sebelum dan sesudah perlakuan teknik rebozo

Ha: Ada perbedaan lama persalinan kala I fase aktif pada ibu primigravida sebelum dan sesudah perlakuan teknik rebozo

Ho diterima bila $\alpha>0,05$

Ha diterima bila $\alpha<0,05$ 
Berdasarkan hasil uji analisis terlihat nilai Sig. (2-tailed) $=0,001(\alpha<0,05)$, artinya Ha diterima, dan Ho ditolak, maka ada perbedaan rata-rata lama persalinan kala I fase aktif untuk pretest dan post test setelah diberikan teknik rebozo. Sehingga dapat disimpulkan ada pengaruh teknik rebozo terhadap lama persalinan kala I fase aktif pada kelompok ekperimen.

Persalinan lama pada ibu primipara apabila persalinan terjadi lebih dari 8 jam untuk fase laten dan lebih dari 6 jam untuk fase aktif dan lebih dari 2 jam untuk kala II. Rata-rata pembukaan pada primipara adalam $1 \mathrm{~cm} / \mathrm{jam}$ sedangkan pada multipara $1 \mathrm{~cm} / 30$ menit. Kontraksi uterus yang kuat apabila 3 x/10 menit dengan durasi 40 detik dalam 1 kontrakri (Cunningham, Leveno, Bloom, Spong, \& Dashe, 2014). Dalam penelitian ini, lama persalinan dinilai dari 3 kriteria yaitu kontraksi uterus, pembukaan serviks dan lama persalinan kala I fase aktif.

Hasil penelitian tentnag pengaruh teknik rebozo terhadap lama persalinan kala I fase aktif pada kelompok ekperimen juga dapat dilihat pada penelitian yang dilakukan oleh Durotun M dkk tentang Manfaat teknik Rebozo Terhadap Kemjuan persalinan yang dilakukan di PMB di Semarang, dengan hasil nilai median setelah dilakukan teknik Rebozo sebesar 10,0 dan kontrol sebesar 9,00. Uji statistic menggunakan Mann-Whitney Test diperoleh selisih p-value antara kelompok intervensi teknik Rebozo dan kontrol sebesar 0,018 < 0,05 maka Ha diterima artinya ada perbedaan efektifitas intervensi dan kontrol terhadap pembukaan serviks ibu bersalin kala I fase aktif, sehingga disimpulkan bahwa terdapat efektivitas pemberian teknik Rebozo terhadap pembukaan serviks dan penurunan kepada janin pada ibu bersalin kala I fase aktif dan teknik Rebozo sangat bermanfaat terhadap kemajuan persalinan (Munafiah, Astuti, Parada, \& Demu, 2020).

1) Perbedaan lama persalinan Kala I fase aktif pretes dan post test pada kelompok kontrol

Perbedaan lama persalinan kala I fase aktif pada ibu primigravida pre tes dan post tes tanpa perlakuan teknik rebozo (kelompok kontrol) dengan menggunakan Paired $t$ test yang sebelumnya dilakukan uji normalitas data, dapat dilihat pada tabel dibawah ini :

Tabel 4

Perbedaan lama persalinan kala I fase aktif pada ibu primigravida pre test dan post test pada kelompok kontrol $(n=14)$

\begin{tabular}{llllllll}
\hline \multirow{2}{*}{$\begin{array}{l}\text { Kelompok } \\
\text { Kontrol }\end{array}$} & \multicolumn{2}{l}{ Lama Kala I Fase Aktif } & Korelasi & Sig & Sig.(2- \\
\cline { 2 - 7 } & Mean & $\mathbf{N}$ & $\begin{array}{l}\text { Std } \\
\text { tailed) }\end{array}$ & $\begin{array}{l}\text { SE } \\
\text { Mean }\end{array}$ & & & \\
\hline Pre Test & 4,14 & 14 & 0,949 & 0,254 & 0 & 0 & 0,583 \\
\hline Post Test & 4.00 & 14 & 0,00 & 0,000 & & & \\
\hline
\end{tabular}


Tabel di atas dapat di ketahui bahwa rata rata lama kala I fase aktif pada pre test diperoleh 4,14 , sedangkan pada post test diperoleh 4 . Nilai standar deviasi pre test 0,949 dan post test 0,00 . Standar error mean untuk pre test 0,254 dan post test 0,00 . Karena rata - rata lama persalinan pre test $4,14>$ post test 4.00 , maka secara deskriftif ada perbedaan lama persalinan kala I antara pre test dan post test yang mana persalinan sebelum rebozo lebih lama dibandingkan sesudah rebozo.

\section{Uji hipotesis 2}

Ho: Tidak Ada perbedaan lama persalinan kala I fase aktif pada ibu primigravida pre tes dan post test pada kelompok kontrol

Ha: Ada perbedaan lama persalinan kala I fase aktif aktif pada ibu primigravida pre tes dan post test pada kelompok kontrol

Ho diterima bila $\alpha>0,05$

Ha diterima bila $\alpha<0,05$

Berdasarkan hasil uji analisis terlihat nilai Sig. (2-tailed) $=0,583(\alpha>$ $0,05)$, artinya Ha ditolak, dan Ho diterima, maka tidak ada perbedaan rata-rata lama persalinan kala I fase aktif untuk pretest dan post test pada kelompok kontrol. Sehingga dapat disimpulkan tanpa perlakuan rebozo, tidak ada percepatan lama persalinan kala I fase aktif pada kelompok kontrol.

Untuk mempercepat kemajuan persalinan, peneliti memberikan intervensi teknik bersalin kepada ibu bersalin yang secara signifikan dimana pada kelompok intervensi kemajuan persalinan lebih cepat daripada kelompok kontrol. Karena itu peneliti merasa intervensi perlu diberikan kepada ibu bersalin untuk dapat mempercepat kemajuan persalinan. Beberapa penelitian yang melakukan intervensi kepada kelompok intervesi dan tidak melakukan intervensi kapada kelompok kontrol untuk melihat pengaruh dalam mempercepat kemajuan persalinan.

Penelitian (AGMA, 2019) tentang pengaruh pelaksanaan pelvic rocking dengan birth ball terhadap kemajuan persalinan di Klinik Pratama Tanjung Deli Tua menggunakan teknik pelvic rocking dengan birth ball yaitu cara menambah ukuran rongga pelvis dengan menggoyang panggul di atas bola yang sangat efektif membantu merespon rasa sakit dan mengurangi lama persalinan kala I fase aktif. Kemajuan persalinan untuk status birth ball dilakukan memiliki ratarata sebesar 143 menit dengan simpangan baku sebesar 49,63 sedangkan pada status birth ball tidak dilakukan memiliki rata-rata kemajuan persalinan sebesar 281 menit dengan simpangan baku sebesar 81,27 dimana ratarata kemajuan persalinan untuk status birth ball dilakukan dan tidak dilakukan adalah berbeda (two-tailed) dan lebih cepat sebesar 138,2 menit dibandingkan status birth ball tidak dilakukan dengan nilai pvalue sebesar $0,00001<0,05$. Kesimpulannya terdapat pengaruh yang bermakna antara pelaksanaan pelvic rocking dengan birth ball terhadap kemajuan persalinan (AGMA, 2019). 
Penelitian (Astuti \& Noviyanti, 2015) tentang Pengaruh Hypnobirthing Terhadap Tingkat Nyeri Dan Kemajuan Persalinan Pada Ibu Bersalin Di Bpm Kota Cimahi, digunakan teknik hypnobirthing dimana ibu hamil diajarkan untuk menenangkan pikiran dengan cara fokus dan diikuti dengan self-hypnosis dengan kalimat afirmasi dan sugesti untuk mencapai kelahiran yang sehat, nyaman dan lancar. Hasil analisis yang diperoleh menunjukkan bahwa nilai $\mathrm{p}$ tingkat nyeri adalah 0.001, yang artinya bahwa terdapat pengaruh hypnobirthing yang signifikan terhadap penurunan intensitas nyeri dan 0.038, yang artinya bahwa terdapat pengaruh hypnobirthing yang signifikan terhadap kemajuan persalinan. Kesimpulan menunjukkan ada pengaruh hypnobirthing terhadap intensitas nyeri dan kemajuan persalinan (Astuti \& Noviyanti, 2015).

Pijatan mempunyai tingkat efektivitas yang cukup tinggi dalam menurunkan nyeri persalinan. pijat merangsang tubuh melepaskan senyawa endorphin yang merupakan pereda rasa sakit alami. Selain itu teknik pijatan mampu mengendurkan ketegangan dan membantu menurunkan emosi dengan merelaksasi dan menenangkan saraf, serta membantu menurunkan tekanan darah. Banyak bagian tubuh ibu bersalin dapat dipijat, yaitu pada bagian kaki, punggung, bahu, tangan, belakang sarkum. Hasil penelitian menunjukkan bahwa perbandingan tingkat intensitas nyeri pada kelompok kontrol pada pre test dan post test menunjukkan $\mathrm{p}=$ 0,051>0,05 yang berarti tidak terdapat perbedaan intensitas nyeri sebelum dan sesudah perlakuan pada kelompok kontrol. Sedangkan perbandingan intensitas nyeri pada kelompok yang mendapatkan kombinasi teknik relaksasi dan pijatan pre test dan post test diperoleh hasil $\mathrm{p}=0,001<0,05$ yang berarti terdapat perbedaan yaitu adanya penurunan intensitas nyeri sebelum dan sesudah pemberian kombinasi teknik relaksasi dan pijatan terhadap lama waktu persalinan dengan indikator pembukaan serviks $(\mathrm{p}=0,000)$. Penerapan kombinasi teknik relaksasi dan pijatan dapat digunakan sebagai bagian integral dalam memberikan asuhan dasar pertolongan persalinan untuk membantu ibu mengurangi nyeri persalinan dan mempercepat proses persalinan.

2) Pengaruh teknik rebozo terhadap lama persalinan kala I post ekperimen dan post control

Untuk melihat apakah ada pengaruh terapi rebozo terhadap lama persalinan kala I fase aktif antara kelompok intervensi yang mendapatkan perlakuan rebozo dan kelompok kontrol yang tidak mendapatkan perlakuan, dilakukan dengan menggunakan uji Independent sample test, yang dapat dilohat pada tabel 5.9 dibawah ini:

\section{Tabel 5}

Perbedaan Lama Persalinan Kala I Fase Aktif Pada Kelompok Intervensi dan Kelompok Kontrol $(\mathbf{n}=\mathbf{2 8})$

\begin{tabular}{|c|c|c|c|c|c|c|c|}
\hline \multirow[b]{2}{*}{$\begin{array}{l}\text { Teknik } \\
\text { Rebozo }\end{array}$} & \multicolumn{4}{|c|}{ Lama Kala Fase Aktif } & \multirow[b]{2}{*}{ Korelasi } & \multirow[b]{2}{*}{ Sig } & \multirow[b]{2}{*}{$\begin{array}{l}\text { Sig. } 2 \\
\text { tailed }\end{array}$} \\
\hline & Mean & $\mathrm{N}$ & SD & $\begin{array}{l}\text { SE } \\
\text { Mean }\end{array}$ & & & \\
\hline Post Test Intervensi & 7,43 & 14 & 1,342 & 0,359 & 26 & 0,000 & 0,000 \\
\hline
\end{tabular}




\begin{tabular}{lllll}
\hline Post test Kontrol & 4.00 & 14 & 0,000 & 0,000 \\
\hline
\end{tabular}

Berdasarkah hasil olah data uji independent sampel t test, nilai rata-rata lama persalinan kala I untuk ibu yang mendapat perlakuan teknik rebozo didapatkan sebesar 7,43 dan untuk ibu yang tidak dilakukan teknik rebozo sebesar 4. Nilai mean rank intervensi teknik rebozo $(7,43)>$ kontrol $(4 ., 00)$ yang berarti bahwa teknik rebozo lebih efektif terhadap percepatan persalinan kala I fase aktif. Ini berarti dapat disimpulkan bahwa ibu yang menggunakan teknik rebozo ternyata lama persalinannya lebih cepat.

\section{Uji hipotesis 3}

Ho: Tidak ada perbedaan lama persalinan kala I fase aktif pada ibu primigravida kelompok intervensi dan kelompok kontrol

Ha: Ada perbedaan lama persalinan kala I fase aktif pada ibu primigravida kelompok intervensi dan kelompok kontrol

Ho diterima bila $\alpha>0,05$

Ha diterima bila $\alpha<0,05$

Berdasarkan hasil uji analisis terlihat nilai Sig. (2-tailed) $=0,00(\alpha<0,05)$, artinya Ha diterima, dan Ho ditolak, nilai mean rank intervensi $(7,43)>$ kontrol $(4 ., 00)$ yang menunjukkan ada perbedaan rata-rata lama persalinan kala I fase aktif setelah perlakuan teknik rebozo pada kelompok ekperimen dan kelompok kontrol, maka dapat disimpulkan teknik rebozo efektif untuk mempercepat lama persalinan kala I fase aktif. Dalam penelitian ini lama persalinan dinilai dalam 3 kategori yaitu Kontraksi uterus, pembukaan serviks, dan lama kala I fase aktif.

Sesudah 36 minggu kontraksi uterus akan meningkat hingga persalinan mulai. Kontraksi uterus lebih kuat setiap sepuluh menit dan serviks membuka $2 \mathrm{~cm}$. Kontraksi uterus yang sempurna mempunyai kejang otot paling tinggi di fundus uteri yang lapisan ototnya paling tebal dan puncak kontraksi terjadi simultan diseluruh bagian uterus. Sesudah tiap his, otot-otot corpus uteri menjadi lebih pendek daripada sebelumnya (retraksi), sementara serviks yang sedikit mengandung otot tertarik keatas dan terbuka, membuat pembukaan menjadi lebih cepat. Pada Kala persalinan frekuensi kontraksi menjadi 2 sampai 4 kontraksi tiap 10 menit, dengan lama yang meningkat dari 20 detik pada permulaan partus sampai 60-90 detik pada akhir kala I atau permulaan kala II.

Hasil penelitian ini sesuai dengan penelitian yang dilaksanakan (Munafiah et al., 2020) di Praktek Mandiri Bidan Semarang tentang manfaat teknik rebozo terhadap kemajuan persalinan, dengan menggunakan uji Mann -Whitney Test yang menyatakan ada perbedaan efektifitas intervensi dan kontrol terhadap pembukaan serviks ibu bersalin kala I fase aktif dengan $p$ value 0,028 . Nilai mean rank intervensi teknik rebozo 13,30 lebih besar dari nilai kontrol yaitu 7,70 yang berarti bahwa teknik rebozo lebih efektif terhadap pembukaan serviks ibu bersalin kala I fase aktif (Munafiah et al., 2020). 
Nyeri pada persalinan merupakan proses yang fisiologis. Nyeri yang dirasakan saat bersalin merupakan indikator sedang terjadinya pembukaan dan dilatasi pada serviks. Nyeri yang tidak bisa diatasi oleh ibu bersalin dapat mempengaruhi kondisi ibu berupa kelelahan, frustasi, putus asa dan menimbulkan stress. Sebaliknya stress dapat menyebabkan melemahnya kontraksi rahim dan berakibat pada persalinan yang lama. Apabila hal ini tidak cepat teratasi maka dapat menyebabkan kematian pada ibu dan bayi. Penyulit bagi ibu adalah persalinan lama, kecemasan, ketidaknyamanan dan bagi bayi bisa mengakibatkan hipoksia.

Bidan homebirth AS, Gail Tully menunjukkan bahwa ketegangan di dalam ligamen pelvis dapat berdampak pada ruang yang harus ditempuh bayi di dalam rahim, teknik tersebut adalah Shifting yang dilakukan dalam rebozo dengan meminta ibu dalam posisi merangkak, atau meletakkan tubuhnya sambal memeluk birthball atau berdiri sambal memegang kursi. Ketika merasakan kontraksi, pendamping persalinan akan menarik kain dan menggoyang-goyangkan bagian perut ibu secara lembut seperti gerak mengayak. Gerakan ini dapat mengurangi nyeri kala I karena adanya relaksasi diperut bagian bawah dan membuat ini merasa lebih nyaman. Lilitan yang tepat akan membuat ibu merasa dipeluk dan memicu keluarnya hormon oksitosin atau hormon senang supaya persalinan ibu lebih lancar, sehingga dapat mempercepat persalinan kala I.

Teknik rebozo berikutnya adalah teknik shake the apple tree, lebih cenderung ke ligament otot panggul sehingga dapat mengurangi rasa sakit di pinggang. Teknik ini dilakukan dengan mengerakkan pelan-pelan bagian bokong ibu sesuai kenyamanan menggunakan selendang dan kedua tangan menopang pada Bola gym atau dapat menggunakan kursi sofá dilapisi bantal. Lamaze dalam Bobak menyatakan bahwa 85-90\% persalinan berlangsung dengan nyeri, dan hanya 10$15 \%$ persalinan yang berlangsung tanpa rasa nyeri.

Menurut Diana (2018) dalam artikel Rebozo Technique: Membantu Persalinan Lebih Nyaman dengan Kain Jarik, untuk mendapatkan persalinan yang nyaman dilakukan teknik Rebozo dimana pasangan akan melilitkan kain jarik di bagian perut ibu ketika ibu mulai merasakan kontraksi, pendamping persalinan akan menarik kain dan menggoyang-goyangkan kain bagian perut ibu secara lembut. Lilitan yang tepat akan membuat si ibu merasa seperti dipeluk dan memicu keluarnya hormone oksitosin yang bisa membuat proses persalinan lebih lancer. Tidak hanya sebatas kenyamanan saat persalinan, Rebozo juga membantu memberikan ruang pelvis yang lebih luas untuk ibu sehingga bayi lebih mudah menuruni panggul dan proses persalinan menjadi lebih cepat (Diana, 2018).

\section{Kesimpulan}

Karakteristik ibu bersalin primigravida pada kelompok intervensi dan kelompok kontrol semuanya pada usia reproduksi yaitu 20-35 tahun, umumnya pendidikan SMA yaitu $57,4 \%$ pada kelompok intervensi dan $85,8 \%$ pada kelompok kontrol. Jenis 
Efektifitas Teknik Rebozo dalam Lama Persalinan Kala I Fase Aktif pada Ibu Bersalin Primigravida di Wilayah Kabupaten Tapanuli Utara Bulan Januari s/d Oktober 2020

pekerjaan umumnya PNS $57,4 \%$ pada kelompok intervensi dan $71,4 \%$ pada kelompok kontrol. Semua persalinan didampingi oleh suami.

Teknik rebozo sangat efektif untuk mempercepat lama persalinan kala I fase aktif yang diperoleh dengan menggunakan uji independent $\mathrm{t}$ test nilai $\alpha=0,00(<0,05)$, nilai mean rank menunujukkan ada perbedaan rata-rata lama persalinan kala I fase aktif kelompok intervensi $(7,43)>$ kelompok kontrol $(4 ., 00)$

\section{BIBLIOGRAFI}

Agma, Annisa A. L. Faiq. (2019). Pengaruh Pelaksanaan Pelvic Rocking Dengan Birth Ball Terhadap Kemajuan Persalinan Di Klinik Pratama Tanjung Deli Tua Tahun 2018. Google Scholar

Arikunto, Suharsimi. (2010). Metode Peneltian. Jakarta: Rineka Cipta. Google Scholar

Astuti, Indria, \& Noviyanti, Noviyanti. (2015). Pengaruh Hypnobirthing Terhadap Tingkat Nyeri Dan Kemajuan Persalinan Pada Ibu Bersalin Di Bpm Kota Cimahi. SEAJOM: The Southeast Asia Journal Of Midwifery, 1(1), 43-47. Google Scholar

Cahyati, Yanti, Nurachmah, Elly, \& Hastono, Sutanto Priyo. (2013). Perbandingan Peningkatan Kekuatan Otot Pasien Hemiparese Melalui Latihan ROM Unilateral Dan Bilateral. Jurnal Keperawatan Indonesia, 16(1), 40-46. Google Scholar

Cunningham, F., Leveno, Kenneth, Bloom, Steven, Spong, Catherine Y., \& Dashe, Jodi. (2014). Williams Obstetrics, 24e. Mcgraw-Hill New York, NY, USA. Google Scholar

Hidayat, Aziz Alimul. (2007). Metode Penelitian Kebidanan Dan Analisa Data. Jakarta: Salemba Medika. Google Scholar

Munafiah, Durrotun, Astuti, Lestari Puji, Parada, Mike Mitrasari, \& Demu, Maria Rosa Mictica. (2020). Manfaat Teknik Rebozo Terhadap Kemajuan Persalinan. Midwifery Care Journal, 1(3), 23-27. Google Scholar

Notoatmodjo, Soekidjo. (2012). Metodologi Penelitian Kesehatan. Google Scholar

Riskesdas, L. (2013). Badan Penelitian Dan Pengembangan Kesehatan. Jakarta: Kementerian Kesehatan RI. Google Scholar

Rukiah, Yeyeh. (2009). Et All. 2009. Asuhan Kebidanan I (Kehamilan). Google Scholar

Simbolon, Ganda Agustina Hartati, Siburian, Urhuhe Dena, \& SKM, M. Kes. (2021). Menguji Efektifitas Teknik Rebozo Dalam Persalinan. Media Sains Indonesia. Google Scholar

\section{Copyright holder:}

Eko Prasetyo, Ivan Anindito Arista, Rudi Hermawan, Erlanda Pane (2021) 
Ganda Agustina Hartati Simbolon, Urhuhe Dena Siburian

First publication right:

Syntax Literate: Jurnal Ilmiah Indonesia

This article is licensed under:

(c) (i) (?) 